\title{
Miranda
}

Revue pluridisciplinaire du monde anglophone /

Multidisciplinary peer-reviewed journal on the English-

speaking world

15 | 2017

Lolita at 60 / Staging American Bodies

\section{Bodies of War and Memory: Embodying, Framing and Staging the Korean War in the United States}

Thibaud Danel

OpenEdition

Journals

Electronic version

URL: http://journals.openedition.org/miranda/10494

DOI: 10.4000/miranda.10494

ISSN: $2108-6559$

Publisher

Université Toulouse - Jean Jaurès

Electronic reference

Thibaud Danel, "Bodies of War and Memory: Embodying, Framing and Staging the Korean War in the United States", Miranda [Online], 15 | 2017, Online since 18 September 2017, connection on 16

February 2021. URL: http://journals.openedition.org/miranda/10494 ; DOI: https://doi.org/10.4000/

miranda.10494

This text was automatically generated on 16 February 2021.

\section{(c) $($ ) $(9)$}

Miranda is licensed under a Creative Commons Attribution-NonCommercial-NoDerivatives 4.0

International License. 


\title{
Bodies of War and Memory: Embodying, Framing and Staging the Korean War in the United States
}

\author{
Thibaud Danel
}

1 This study of the Korean War (1950-3) endeavors to analyze the war phenomenon in its countless bodily representations of then and now. Based on the distinction that war and memory are fundamentally embodied, this diachronic research will make the best of the specificities of the war in Korea to inquire into the porous nature of the theoretical line that historically relates and yet inevitably divides the two. Since bodies are shaped by war as much as they shape war, bodies of memory can indeed be expected to abide by the same dynamics.

2 The overall purpose of this paper is to determine why war can be described as an embodying event or, more specifically, how the bodies of war contribute to shape the bodies of memory and thereby affect how the war will be remembered. As representations, bodies shape the cultural and historiographic divide that still exists between the different actors of the Korean War. Whereas in the United States the conflict became known as the "Forgotten War" after British historian Clay Blair published his famous The Forgotten War: America in Korea, 1950-1953 (1987), it remains very actual in the Korean Peninsula where new bodies are still being found today. And yet, as many scholars have suggested, the war has been forgotten on the US soil because it took place far from home, in "a country they did not know" (as the plaque reads at the Korean War Memorial in Washington, DC) and, apart from the revisionists, who argued that the war was a civil war and consequently moved away from the traditional 'free world vs. communism' paradigm, most people still overlook its local causes and consequences.

3 A first concern, then, in dealing with the use of bodies in a process of remembrance and forgetfulness, will be to address the corporeality of war in theory before attention is paid to the Korean War itself. To start with, it will be compelling to determine to what extent the body (as a concept encompassing numerous bodies) can not only represent, 
but also relate war. Drawing on what M. Joly once called the "body-war diptych", this paper will then take the case of the Korean War to study how the American body was framed in the war theater during the war. Finally, it will reflect on the memorialization of the bodies of war as a staging process shifting the focus away from the war onto its remembrance and commemoration.

\section{Theoretical framework}

4 Using the corporal metaphor of birth to describe the causal relationship that exists between war and history, French polemologist G. Bouthoul once argued that "History was born out of war." ${ }^{1}$ For that reason, war ranks among the oldest topics of historiography. Since it is "fundamentally embodied," as it was more recently argued, the war phenomenon "occupies innumerable bodies in a multitude of ways." (McSorley 1) If the war phenomenon is indeed an embodying event, it suggests that the body is the smallest common denominator to represent war. In this respect, bodies are endowed with some relational quality enabling them to relate war, in all the meanings of the term. Conversely, as it will be contended, they can also be denied their relationality and be reduced to "invulnerable" war machines as soon as they are given a function that serves the State apparatus, and become part of it.

\section{The body and the representation of war}

5 Despite its apparent centrality, the body struggled to make its mark in official war histories which often remain as remote from the soldiers who fought them as from the civilians who died because of them. ${ }^{2}$ As disembodied war histories failed to offer any critical thinking about the bodies of war, it might appear that the day-to-day corporeal experience of war has mostly been neglected to the benefit of more quantitative approaches to war historiography. For that reason, the Korean War is often remembered for the total number of US military deaths it caused, estimated at 54,246 by the Pentagon, after only three years of conflict. By comparison, total US military deaths for the Vietnam War were estimated at 58,209 (between 1961 and 1975). Counting bodies, as during the Vietnam War, was also a means to determine which side was winning. Such quantitative reductionism cannot comprehensively account for the cultural and political realities constitutive of war. Though it may certainly conjure up a clear picture of how ferocious the Korean War was in retrospect, it fails to give full account of the dead bodies of war as socialized constructs (Lock 135) and might eventually prove erroneous. ${ }^{3}$

6 As the etymology of the phrase suggests, the corporal reality of war (or corporeality) cannot be reduced to casualty statistics, body counts and other miscellaneous data sources, especially when they exclude non-military personnel or indigenous civilian victims. As it involves actors other than soldiers, war is unmistakably more than just the sum of a belligerent's total military deaths. A more organizational approach to the corporeality of war reveals that the body, in its most abstract interpretation, is also used to represent the United Nations as "a world body" that excluded North Korea but acknowledged the sovereignty of South Korea; or any other "political body" beyond the military-civilian dichotomy. In this respect, other relevant occurrences include 
"propaganda" bodies and, perhaps more interestingly, bodies "still in existence" like UNTOCK (Sandler 2015). ${ }^{5}$

7 In more linguistic and rhetorical terms, when war historians qualify the body (for example, the "demoralized body" of a platoon mentioned by Hastings 2015), they insist on more qualitative aspects of historical research and provide a view from the ground, giving access to the multiple layers of reality making up not only the war phenomenon, but also the human experience of war. By the same token, historians may also use the concept to refer to the "body of records" that they used to build their narrative, and posit it as more or less reliable. ${ }^{6}$ All these different meanings exist because the body is a relational concept in the first place.

\section{The body as a relational concept}

8 In a cultural perspective, the body is thus the least common denominator to grasp what is meant by the corporeality of war. As it embodies war, the body must be understood as something more than a representation. As prolific scholar K. McSorley recently demonstrated, war is enacted and reproduced through some "affective dispositions, corporeal careers, embodied suffering, and somatic memories that endure across time and space" and the body implies a myriad of "embodied practices, structures of feeling and lived experiences" through which the war phenomenon "lives and breeds." (McSorley 1-2) Already in Kant's transcendental approach to the body, embodiment referred to the forms of intuition which constitute a subject's experience (Hengehold 90). Drawing on the Kantian body, Deleuze suggested that it had to be conceived as an intensive reality (Parr 37).

The concept of corporeality lies at the crossroads between history and memory. Taken as a relational concept or as a "relational thing" (Harvey 98), the body models the boundaries between real experience and knowledge, on the one hand, and psychological events, or acts of speculation and imagination, on the other (Hengehold 105). War, understood as a set of intersubjective and interactive bodily practices, is regulated by formally distinct codes which vary from one culture to another and give the war its color. As suggested by many Korean War Memorials, for instance, the most recurring feature giving the war its color would be the nylon twill hooded ponchos US soldiers used as extra covering for warmth or to produce tent shelters in the winter. Initially introduced in 1950 (Stanton 244-5), they were integrated into the design of the Korean War Veterans Memorial in Washington DC and that of many other local memorials. Not only do they show "the appetite for mediated representations of war," they also reveal "current popular fears about vulnerability of the body" (McSorley 78, 86-87) and expose a particular body experience as they act as a reminder of the extreme weather conditions those suggestively heroic soldiers found themselves in.

It follows that the body may be described as the product of several "relations," "actions" and "reactions," that is to say, a number of characteristics or qualities that will single it out as the body of a combatant, a victim, a witness, a veteran, an enemy, a hero etc. War being "the most radically embodying event in which human beings ever collectively participate" (Scarry 71), specific modes of embodiment may manifest in various ways to convey the corporeal experience of the war phenomenon and, in turn, shape its memory. This, as it will be argued, presupposes that the embodied nature of 
war and the bodily issues it encapsulates, like corporal violence, can be disavowed as a result of social and cultural conventions. Once deprived of its relational quality, in other words, the body becomes part of the war machine.

\section{The body as war machine}

11 The corporeality of war as a transdisciplinary concept cannot escape some theoretical considerations on politics and culture to understand how the body is shaped in the context of war. Indeed, as Deleuze and Guattari once affirmed, any State apparatus must capture the body of the soldier and shape it into a war machine. Understood as such, the body is shaped by the world of machinery (Pick 212), which means that it is disciplined and transformed according to specific expectations whose norms, codes and territories are fixed by culture and may-or may not-vary from one conflict to another. In fact, the evolution of the body seems to be determined not only by the damage war inflicts upon it, but also by an interplay of specific bodily practices, from prewar military training to post-war memorial ceremonies, regulated by the control mechanisms and institutions constitutive of what M. Foucault called the "anatomopolitics of the human body" or biopower (Foucault 1990, 135-136).

Though unquestionably theoretical, this problem of power relations between the military and politics popped up in many instances throughout the Korean War, most notably in debates over the use of the nuclear bomb. With the State being deprived of any war machinery of its own (Deleuze and Guattari 2), the dividing line between the military and political power is not invariably clear, even more so in post-war Korea where authoritarian régimes continued to develop immediately after the Panmunjom Armistice Agreement (27 July 1953). Originally rejecting the contention that wars "required the supreme military commander to have absolute leadership in every respect" (Ludendorf), some political theorists (Beck and Clausewitz) agreed on the idea they were essentially a "continuation of politics" (Handel 243).

Since the body becomes both an object and a target of power (Foucault 1991, 136), biopower instigates the dehumanizing tendencies characteristic of war: the way enemy bodies are treated, the prisoner-of-war and repatriation issue, or even cases of corporal violence against non-combatants are all patent manifestations of these tendencies. Conversely, the body as the "site of common human vulnerability" (Butler 2003, 15) implies that any conflict "risks the contingency... of sensory and affective experience of war" (McSorley 9) as it gives all the belligerents the possibility of crossing the friend/ foe divide beyond military imagination and political ideologies (Cole 34). The possibility actually existed during the Korean War because, as a civil war, it opposed the two parts of a country that had never been separated until then: the language and culture were the same on both sides of the $38^{\text {th }}$ Parallel. Considering Korea was separated after Japan's defeat in 1945, this reflected a constant concern on behalf of the men and women who fought to defend a country and a people that they did not know as there was no way non-Korean soldiers could distinguish between the two sides, except by their uniforms. The body, when incorporated to the war machine, negates a part of the corporeal experience of war and limits it to the message the State apparatus wants to vehiculate. 


\section{The bodies of war}

14 Given that the notion of representation is a multifaceted one, it follows that the representation of bodies (the body-image) must be distinguished from the bodily experience of war (the lived body). This in turn suggests that the body should be understood as an all-encompassing concept wavering between the different models we introduced. To enrich these models, we will consider three different media that served to "frame" the Korean War to analyze how the Korean War was embodied then. In theory, these models echo J. Butler's thesis that there existed three ways of framing. First, to "bring the human into view in its frailty and precariousness" which arguably corresponds to the lived body in that it insists on the relational quality of the body and "allows us to stand for the value and dignity of human life, to react with outrage when lives are degraded or eviscerated." Second, there are "frames that foreclose responsiveness" which are more redolent of the body-image insofar as they negate one's emotional response and limit the bodies of war to mere representations. There finally exist "alternative frames" whose content "would perhaps communicate a suffering that might lead to an alteration of our political assessment of the current wars" (Butler 2009, 77) which, as it will be contended, roughly echoes the idea that the body can be used as part of the war machine to communicate and condition one's view of the war.

\section{War propaganda}

15 The study of war propaganda provides a first insight into the war phenomenon and its bodily representations. Propaganda indeed cultivates a certain artistic taste of the bodies of war, regardless of the ideology that produces them in the first place (though they reflect different ideologies in the end). In both the Fascist aesthetics used by DPRK and US mobilization posters, soldiers are depicted as strong and proud to serve. ${ }^{7}$ Because national identities always reflect "a body of people who feel that they are a nation," as R. Emerson put it (102), nations (or groups of nations) can thus be embodied, just as the soldiers and the civilians embody different aspects of the same war. As such, body-images of soldiers making the Korean War were meant to stand for specific ideals and reflect a particular national and historiographic discourse accordingly.

Every belligerent in the war theater used more or less artistic images of the body for propaganda, though in different ways. Yet all have in common that nations were embodied by, at least, one body, preferably a soldier but not exclusively. North of the $38^{\text {th }}$ Parallel, soldiers were represented in the form of "idealized bodies" symbolizing North Korea's military might and determination while the "frail bodies" of women and children were used to denounce US misdeeds, thereby blurring the boundary between the body-image and the lived body. Conversely, enemy bodies tended to be vulgarized to the extreme. In North Korea, propaganda posters in English were sometimes made to lull American soldiers out of the war. On one of them, an obese Uncle Sam is shown making money out of the blood of soldiers and putting it in a big bag with the inscription "war profits" written in big red letters. ${ }^{8}$ Furthermore, the body of war captives could be used for propaganda (Young 2014,59), in Maoist China (Issermann 102) as in South Korea. ${ }^{9}$ 
17 In propaganda as in military strategy, the body personifies the war phenomenon and can be used to play on the power of affect to turn public opinion for or against the war. ${ }^{10}$ In the 1952 presidential campaign, the Republican Party cited the high-and often exaggerated-number of casualties to gain in popularity (Young 2014,18). Aside from partisan and ideological rifts, both national and international, new historians-though in reality the idea was not so novel (Stone 1952)-have also emphasized that the US had to "sell" (Barron 18) the Korean War to similarly influence public opinion at a time when drastic cuts on the defense budget had been made. War propaganda then capitalized essentially on a "blood campaign" (Casey 323) promoting not only the importance of medical teams in Korea, but also the role of women in the fighting, ${ }^{11}$ as during the Second World War.

Of course, body representations used in war propaganda emphasized very little of the corporeal experience of war because they had an irremediable political character causing the bodies of war to be reduced to national identity and ideology, hinging on the war machine model. While North Korea made-and still makes-posters to suggest the violence committed by (or against ${ }^{12}$ ) American invaders, the South tended to appeal directly to the enemy and referred to the common experience of the front to convey their political ideas. Consistent with the psychological warfare tactics promoted by the US Far East Command when the war broke out, South Korean leaflets thus depicted the United Nations instead of the US, ${ }^{13}$ turning the American body into a larger geopolitical "world body" while, on the contrary, North Korea tended to limit it to the US exclusively (Sandler 2002, 201).

\section{War pictures}

As they sometimes happened to be used for propagandistic purposes, war pictures (in the loose sense of the term, thus including movie pictures) make up another area of investigation into the bodily representations of the conflict in Korea because they seemingly take a more invigorating look at the war phenomenon and acquire their meaning through the discourse they communicate (Barthes 1964, 67-68; Barthes 1970). In the early days of the war, leaflets issued by the UN comprised pictures of soldiers taking military training or helping the locals to promote the idea that this was a "collective action to enforce peace," that all the nations engaged in Korea were fighting under "a flag that stands for peace, collective security and the progress of all peoples," that the people were welcoming (UN-DPI). This certainly reflected the official discourses of the Truman years, and especially MacArthur's, because the Korean War was effectively considered as another "crusade" (Diehl 13) in the aftermath of the Second World War. Soldiers were thus to abide by a Just War doctrine they were supposed to embody to make American participation to the conflict legitimate.

In the first months of the war the media reflected official political and military thinking, as the picture of MacArthur in the $10 \mathrm{July} 1950$ issue of Time embodying Truman's "police action" suggests (with the caption "His job: to police the boundaries of chaos"). Journalism had by then already become "a primary companion to war" (Cole 32) which meant that war correspondents and photojournalists were regularly commanded to limit their coverage of military operations in the war theater, thereby impacting on the mediation of the Korean conflict between the public on the home front and the soldiers in the battlefield. It did not mean that they moved away from the 
corporeal experience of war, but they surely selected certain pictures to reflect official views, even after the war, as shown for example in a photograph where an American soldier is seen standing amongst the dead bodies of his brothers-in-arms (Potter 1954). official war reports generally focused on Communist war crimes, fiddling with different quantitative and qualitative representational strategies of depicting bodies to exacerbate ideological rifts (Young 2014).

The representations of American bodies of war changed in December 1950 after MacArthur decided in favor of censoring any picture that would contradict Truman's National Security Council's top-secret document known as NSC-68. The latter is pivotal to understand how the war was to be depicted at home: soldiers fighting under the UN flag embodied not only the polarization of power opposing "the slave society" and "the free world", but also "the rapid buildup of the political, economic, and military strength of the free world" as the document reads. ${ }^{14}$ After photojournalist David D. Duncan published a photo-essay for Life, the press began to use his quite antiheroic images of ordinary soldiers facing danger away from home to question the war's goals (Marien 334-335). Among these were pictures that broke with the usual depictions of the war as they showed handfuls of wounded soldiers, sometimes even carrying improved machine guns as they were ill-equipped, as well as corpses piled away in a truck. Instead of pride, power and freedom, their bodies suggested pain, sorrow, powerlessness or even death (only the boots of dead American privates were shown).

Given that they were inspired by reports provided by official discourses, war films-like war pictures-were controlled too. Despite such restrictions, S. Fuller's Fixed Bayonets (1951) started a cinematographic tradition that has remained quite a recurring theme in Korean War historiography and commemoration. Fuller's previous movie (The Steel Helmet, 1951), the first American movie to depict the Korean War, had already reworked the conventions of the movie genre as it introduced a cynical war veteran who reflected Fuller's views (whereby individualism is necessary for survival), but the movie was never really considered as subversive as Fixed Bayonets (except by Victor Riesel). ${ }^{15}$ In the absence of any "Ramboesque" heroes (a phrase used by historian Paul M. Edwards in his Guide to Films on the Korean War), the latter paid much attention to the lived experience of war as it depicted the bodies in dismay of exhausted US soldiers as well as the psychological warfare and internal dissensions they were confronted to on the battlefield, especially in the cold of winter.

In Fixed Bayonets, US soldiers are deprived of their humanity. This dehumanizing inclination is reflected in shots showing disembodied legs running, thereby obfuscating or disfiguring the aesthetic characteristics of the war body and leaving only a biological and powerless body instead, a form without content. The film shows privates of different nationalities evoking their living conditions on the battlefield, a means that Fuller used to share his own war experience during the Second World War. His film employed many actors but only a handful among them were credited. In full gear, during the night, they are barely recognizable, perhaps to make them more like ordinary, unexperienced people and bring their vulnerability into the open. What makes the movie even more compelling, however, is how the bodies of soldiers become like narratives, moving away from an action-based depiction of war to start asking questions about it. 


\section{War narratives} to investigate, generally fall into two denominations: "there are those that [...] capture the carnage and turn that imagery into antiwar statements and there are those that simply use the topic as an occasion for heroic adventure." (Fuller vII) While Fuller's arguably escaped both, these two categories have in common that they shed light on the narrative aspect of framing bodies that become scripted: on the one hand, in the form of normative binaries like heroes and antiheroes, allies and enemies, aggressors and victims, paragons and counterexamples etc. On the other hand, in the form of alternative frames which, as Butler assumed, "reveal human vulnerability and spark political response" (Conley-Zilkic 327) as in Fixed Bayonets in which the rear guard platoon deals with "people that are not exactly friendly" rather than enemies.

As he wanted to turn his wartime recollections of the Second World War into a screenplay (Fuller VIII), Fuller used the Korean War to emphasize depression and fatigue, the war experience the bodies that lived it: "You're not aiming at a man. You're aiming at the enemy. Once you're over that hump, you're a rifleman." War bodies are dehumanized and mechanized as the enemy becomes something other than a man, while the shooter becomes something more than a man (a "rifleman"), like a hybrid. This quote not only illustrates the body as a war machine, it also mirrors Butler's alternative frames. What is interesting here is that the soldier makes explicit his realization that he and his brothers-in-arms are war machines, but the very realization also suggests that he is not ready to be like that, a feeling that anyone can relate to. A few brief exchanges are particularly noticeable as they still echo contemporary debates in Korean War historiography:

Private 1: They told me it was going to be a police action.

Private 2: Why didn't they send cops?

Ramirez: Tell me, Sarge, why were we picked for this job ?

Rock: Regiment's saving the cream for the rougher stuff ahead

Whitey: Cream? Well, what are we, skimmed milk ?

As shown by the quotes, in the form of explicit questions, the film mirrors Fuller's political response to the Korean War. As the soldiers are turned into discursive manifestations of that response, they allegedly become textual bodies or, to extend the metaphor, like pieces of testimonial evidence framed by a specific historical and historiographic discourse which will determine the way the frames should be read to make sense as representations. ${ }^{16}$

The point here is that the soldiers embody an alternative discourse. Indeed, it is precisely because the movie asked questions about the war that it was considered subversive. In retrospect, moreover, their narrative has become part of the corpus of war (in textual terms). Such scripted bodies, it must be said, are not limited to fiction. As they reflect specific historical narratives, they may also be found in non-fiction as, for instance, in the Korean War Atrocities Report to the Senate published as a result of Korean War hearings which took place in early December 1953, 128 days after the Armistice Agreement was signed (Potter 1954). The hearings compiled the testimonies of veterans focusing on Communist war crimes only. The corporal mistreatment of POWs was regularly emphasized as the testimonies described the physical abuse and torture inflicted on US soldiers. It is not surprising to find congruence between fiction 
and non-fiction in the cultural representations of the war, such as in the movie The Steel Helmet (1951) where some North Korean soldiers are shown dressed as civilians. The tendency of using one's body to trick the enemy was mentioned in the battle reports, which were later used to write and justify the most "abhorrent" aspects of the war. ${ }^{17}$

Conversely, the Chinese National Red Cross published a compilation of testimonies by American (and British) soldiers which it presented to the UN during the war, hence turning the war machine against itself. Although it was quickly dismissed as war propaganda, the report was entitled Out of Their Own Mouths and focused on the corporal violence inflicted on Korean locals by the soldiers, like the collective rape of a thirteen-year old, native civilians who were buried alive, napalmed bodies, the frequent bombing of non-military personnel, mass graves etc.

There were three or more ditches in which a mass heap of dead bodies was strewn about. [...] There were probably 1,000 or more human beings. [...] The rotten odor of human flesh laid heavy on the morning breeze (National Red Cross of China, 43-44).

Other cases of corporal violence in the Chinese report mentioned that American soldiers had been instructed to shoot at anything dressed in white (IV), mutilated bodies with their hands tied behind their backs (20), bodies dismembered by US soldiers such as those of local women whose wombs were ripped open by bayonets (49) etc. All these allegations certainly desacralized American soldiers as it compared the US to Nazi Germany and Imperial Japan while it naturally celebrated the good treatment of captives, north of the $38^{\text {th }}$ Parallel.

\section{The bodies of memory}

30 Today, such cases of bodily violence evoke current and continuing debates in Korean War historiography, notably after the Nogeun-Ri Incident raised the genocide question. ${ }^{18}$ They show us how the bodies of war were staged to establish a friend/foe divide. In this part, it will be compelling to analyze why the bodies of war did more than simply serve propagandist purposes on both sides. By shaping the bodies of memory, the bodies of war also determined its historiography and coincidently gave new life to oral histories either supporting or rejecting it. Indeed, it will be argued that, through the staging of the bodies of memory, the legacy of testimonies and the memory of historical events-what P. Bourdieu would have called the "memory pad" of the body to designate its accumulated history (Bourdieu 2000,141)-have thus challenged the informative or evaluative speech and acts of language (what R. Barthes called "la parole informative" ${ }^{19}$ ) that seem to constitute consensus narratives about the Korean War and how it should be remembered.

\section{Memorializing the bodies of war}

The memorialization of war bodies taken as discursive productions mediatized by language cannot be alienated from the social practice making them knowledgeable. ${ }^{20}$ Taking bodies of memory as social forms redolent of Bourdieu's habitus ${ }^{21}$ is an effective approach to understand how narratives about the body are built in the practice of justification and reformulation, "like a social project of mutual cooperation and of discursive change" (Andrieu 14). The staging of bodies of memory through the process of memorialization and rememoration (Nora) implies that the meanings that the bodies 
of war convey are produced and reproduced during collective acts of remembrance. In this respect, the memorialization of the Korean War cannot simply be explained by the "memorial mania" (Doss 2010) that has swept across the US since the 1980s. Many of these bodies of memory were produced to fit into the design of war memorials. Given that most were the result of local initiative, these memorials virtually reflect the democratization and ensuing multiplication of "private memories" foreshadowed by P. Nora (292). Although they all have in common that they depicted the lived experience of war, the way they were staged may also differ considerably from one state to another, reflecting a divided body of nations with different local concerns and, to some extent, different visions of the events.

In theory, each of these memorial sites has some historiographic value in the way bodies were staged to depict scenes of daily life in and behind the front line (the Atlanta memorial dedicated in 1993, the Cape and Islands memorial in Hyannis dedicated in 2000, the Hudson County War Memorial in Jersey City dedicated in 2002 etc.), from the grinding faces of the statues in Washington DC conveying movement, fatigue and depression to the lonely soldier standing still on a map-like representation of the $38^{\text {th }}$ Parallel in Cedar City (Utah), representing trench warfare and suggesting the US never crossed it. As pointed out earlier, most architects chose the nylon twill hooded ponchos soldiers used in the winter to illustrate the Korean War. The statues were made with more or less sophisticated combat boots, perhaps to symbolize the unpreparedness of US soldiers as realistically as possible. ${ }^{22}$ The Korean War Memorial in Springfield, Illinois (dedicated in 1996) chose to emphasize the participation of different branches of the Army embodied by a soldier, a marine, an airman, a guardsman and a sailor set into a bronze bell looking outward.

Bodies used for the memorialization of the Korean War may vary significantly in terms of the representations they give. Yet they all seem to have privileged an arguably informative and factual approach in their respective designs, with some significant exceptions. When the project was voted, it was decided that the Korean War Veterans Memorial in Washington DC, like many other memorials, would incorporate the figures of both total US and UN deaths, though there were little discrepancies in the exact number of deaths. ${ }^{23}$ But unlike local memorials (Pittsburgh notably), it did not include all the names of those who died in Korea. Instead, the ghostly figures in the Wall of Remembrance stand for the forgotten ones, including women and religious minorities (like Jews). Also, and perhaps more surprisingly given its (inter)national resonance, the federal memorial did not include the figures of civilian casualties on both sides or inbetween, unlike, for example, the History Wall in the Texas Veterans' Memorial where the estimated number of civil and military deaths (on both sides as well as in-between) was carved at the top of the main structure. Interestingly, each panel contains part of a narrative of the conflict, with a short section about the pre-war context. What the whole narrative does not indicate, as it reduces the war to informative speech (Barthes), is how they were killed, who took their lives or how those who witnessed, and perhaps even caused, these deaths live(d) with the trauma on both sides.

\section{Unearthing forgotten bodies}

As the concept of representation entails a process of substitution (a thing for a sign), the bodies of war can be remembered just as they can be forgotten. Since the 1980s, and 
the democratization of South Korea in 1987, memories of the conflict have fought back as war bodies began to be unearthed, figuratively and literally. The American veteran's body constitutes one of these "traces" (in Butler's sense of the term ${ }^{24}$ ) challenging Korean War historiography. In the US, evidence of the "return of the veteran" (Edwards) can be found in a couple of quite recent films, T. Burton's Big Fish (2003) and C. Eastwood's Gran Torino (2008), featuring two Korean War veterans coming to terms with their past, though in completely different fashions. ${ }^{25}$ The return of the veteran was also symbolized in magazines (like The Graybeards) published for former servicemen in the form of pictures or letters, as well as in military paintings to call up the role played by some infantry divisions, such as the $40^{\text {th }}$ and $65^{\text {th }}$ Regiments, which included people from the US informal 'empire' (Guam, Northern Mariana Islands, Puerto Rico etc.). ${ }^{26}$ For example, R. Reeves depicted National Guard units from the multiethnic $40^{\text {th }}$ Infantry Regime in The Sunshine Division in Korea (2001) after they were deployed to Korea in February 1952 to relieve the $24^{\text {th }}$ Division. ${ }^{27}$ Similarly, The Borinqueneers (1992) by D'Andrea depicted the $65^{\text {th }}$ Regiment, a Puerto Rican-manned unit that departed Puerto in 1950 on August $26^{\text {th }}$ and sailed to Korea on October $1^{\text {st }}$ (Rottman 34-35), driving back Chinese troops.

Aside from US veterans, Korean civilians provided another trace of the forgotten bodies of the Korean War. As new dead bodies were still unearthed in Korea by the 2000s, different means have been employed to acquiesce the forgotten realities of war, especially after South Korea declassified some archives, including photographs capturing atrocities committed against Korean bodies by the South and endorsed by the US. ${ }^{28} \mathrm{Few}$, however, were reported in the media and US misdeeds in Korea during and after the war have still not been acknowledged, ${ }^{29}$ even after the revelation of the Nogeun-ri Incident for which Clinton disputably apologized. ${ }^{30}$ The news of the massacre did not really surprise American revisionist and post-revisionist Korean War historians who had formerly exploited war photographs incriminating US soldiers to call the violence of the conflict to attention as proof that it was a civil war (Halliday and Cumings). These photographs included pictures of napalmed women and children, or POWs in North Korea. ${ }^{31}$ It follows that the unearthing of the victimized bodies evidences a different image of the US than the one originally intended.

Interestingly, by way of comparison, the strategy of unearthing the forgotten bodies of the Korean War is key to North Korean historiography of the conflict, as evidenced for example in Kim Il-Sung's official biography (Baik 1973). Due to North Korea being a highly centralized state, the official discourse framing the history of the war, which it regards as the continuation of the War of Liberation for the Fatherland ("조국해방전 쟁"), naturally appears to be monolithic when seen from the outside, as it can be found everywhere, such as in museums, movies, posters in the street or during public ceremonies, or even military art. In these paintings, the same propaganda strategies were used-the dehumanized figure of the American soldier suggests his lack of humanity towards the frail bodies of old people, young women and toddlers. It follows that Korean civilian figures who were caught between the controlled body of the US and North Korean soldiers remain unaccounted for in the memorialization of the war. This suggests that while some bodies are sacred, others are unfit and perhaps even abject as they defile official historical discourses by shedding new light on aspects of the war that tend to be forgotten, such as war crimes for example. 


\section{Staging bodies of memory}

As B. Schwartz suggested in his essay on national memory, "commemoration, like ideology, promotes commitment to the world by producing symbols of its values and aspirations." (Schwartz 11) Bodies of memory become enclaved within a particular historiographic reading advocating a totalizing view of the war and fixing its reading accordingly. As a war serves many purposes-in Bouthoul's words, it is "polytélique" (poly + telos) (Bouthoul 40)-American soldiers are consecrated as symbolic bodies of evidence that 'justify' the war as a result of their sacrifice, giving corporate existence to the values and inspirations which condone the course of historic events according to a specific monotelic evolutionary and evaluative historiographic pattern (a single telos) and concurrently exculpate the US from its responsibility in the conflict as they exclude key historic actors (such as North Korea but also China) from collective acts of remembrance. ${ }^{32}$

The key word to illustrate this telos here is "freedom," as found in G. H. Bush's speeches at the time the site for the Korean War federal memorial was dedicated, as well as in the phrase "Freedom is not free" that was used to illustrate it. The latter is a derivative trope which infers meaning to the sacrifice of American bodies. By opposing "the free world" to slavery, instead of emphasizing the struggle for freedom that postcolonial societies were originally going through, this famous phrase also contributed to export the Cold War in every corner of the world in that it gave concrete evidence, to the Western world, of Communist expansionism in post-colonial Asia. For the same reason, in order to represent the free world, the consecration of American bodies of memory was meant to be more inclusive in respect to the diversity of the US population. The Korean War was indeed the first that the US fought with a desegregated-or rather desegregating-army. ${ }^{33}$ By the time it broke out, the "American dilemma" (G. Myrdal) that had ever so slightly threatened the international reputation of the US during the Second World War had (partly) been resolved. ${ }^{34}$

As of today, however, Korean bodies continue to suffer from misrepresentation when it comes to memorializing the civil war that ripped the peninsula in the early 1950s. To be represented, the Korean body has to be consistent with a given set of discourses and practices to fill the signifying blank left by the symbolic function of war in the creation of identities and boundaries in the post-colonial world. If it cannot be consecrated, the Korean body then becomes part of the abject, i.e. what is unfit to depict (like Duncan's pictures at the time). The bodies of war are key to this twofold process of consecration and abjection because, as they are shaped into-and staged as-bodies of memory, they not only become scripted, they also become increasingly politicized and socialized (Grosz 31), like idols-or simulacra. In that respect, they are endowed with more pragmatic functions, nationally and internationally, as they become the location (in Durkheim's sense of the term ${ }^{35}$ ) of specific practices turning them, as objects and targets of power, into nothing more than war machines.

\section{Conclusion}

As entailed by such human phenomena as war and memory, the body does not necessarily reflect a free and self-determining mind. Indeed, not only do wars have strict codes that shape the body, they also become the focus of a broader civilization 
process (Elias) that transcends them inexorably. Bodies of war and memory formalize, in Foucault's terms, the episteme $e^{36}$ of the war, one we tried to deconstruct using the body in all its acceptations, literal and metaphorical. The body proved to be flexible and multidimensional enough a concept to be taken in terms of representations exclusively. Because of its relationality, it clearly raises cultural and historiographic stakes making the understanding of the war phenomenon even more complex because it moves away from traditional paradigms to shift the focus onto the war phenomenon as it was bodily lived and as it was remembered from one country to another. It is also essential to understand what separates the Korean War as it happened from its memorialization, commemoration and politicization on both sides of the Pacific.

What this study tried to show was that, beyond ideologies, the consecration of bodies of war as bodies of memory is pivotal to the religious structuring inherent to the construction of national identities (in the US as in Korea ${ }^{37}$ ) or international identities (the UN) around certain values. When new bodies of war are unearthed, unsurprisingly for a conflict known as the "Forgotten War," they ever so slightly redefine the corporeality of war-how the war was bodily lived-and shed light on aspects of the war that had so far been ignored during its commemoration. As far as US-Korea relations are concerned, there are numerous political and civic implications to this: insofar as the episteme of war constrains alternative discourses, it simultaneously creates the possibility of its own revocation. As it was recently illustrated by the conjoined twins in T. Burton's Big Fish, (South) Korea is now torn between two corporeal realities in which the US has a central role to play, one which it needs not only to remember, but also to acknowledge. On the one hand, there is the Korean War as it is currently presented in US historiography, that is, as a conflict that erupted early in the Cold War, opposing the two blocs and subordinating Korea to their "values." ${ }^{38}$ On the other hand, there is the reality of the Korean War as a post-independence civil war which, due to the meddling of two expansionist superpowers, has torn a whole country into two irreconcilable parts.

This study finally attempted to open new perspectives on the study of war and memory, and what they reveal about civilizations all around the world. Collective acts of remembrance reflecting the periodicities of political life on both sides of the Pacific indicate two antagonistic trends. Firstly, it highlights the formation of an international body of collective memories of war but always in opposition to an antibody or a nobody. As they can dehumanize individual bodies to turn them into enemies, these organizational bodies of memory wield power of legitimate violence. ${ }^{39}$ Secondly, they give birth to a new social force reflecting local and national concerns as they also happen to have been contested. ${ }^{40}$ In any case, Korean War memories hold a determining place in the organization of strategic cultures. As these memories are always the products of a particular historical perception, commemoration endows the disincarnate ghost of the war with a body and shapes it according to specific discursive conventions pulling historic events out of their context and calling into question the cultural peculiarities of all the international actors that it seeks to incorporate into what could be called an exclusive regime of historicity. ${ }^{41}$ 


\section{BIBLIOGRAPHY}

All the references listed below were consulted to write this paper, including some that are not directly cited.

“Best Dressed Men on Main Street!” In Life, Time Inc., 18 September 1950. 158.

"NSC 68: United States Objectives and Programs for National Security". U.S. Department of State, 14 April 1950. In Naval War College Review. vol. XXVII (May-June 1975): 51-108.

Audoin-Rouzeau, Stéphane. "Guerre." In Dictionnaire de l'historien. Ed. Claude Gauvard and JeanFrançois Sirinelli. Paris: PUF, 2015. 314-315.

Barron, Leo. High Tide in the Korean War: How an Outnumbered American Regiment Defeated the Chinese at the Battle of Chipyong-Ni. Mechanicsburg, PA: Stackpole Books, 2015.

Barthes, Roland. “Rhétorique de l'image.” In Communications 4:1 (1964): 40-51.

---. “L'écriture de l'événement." In Communications 12:1 (1968): 108-112.

---. L'empire des signes. Paris: Seuil, 1970.

Basaure, Mauro. "Axel Honneth and Luc Boltanski at the Epicentre of Politics." In The Spirit of Luc Boltanski: Essays on the 'Pragmatic Sociology of Critique'. Ed. Simon Susen and Bryan S. Turner. New York: Anthem Press, 2014. 391-411.

Bellah, Robert C. "Durkheim and Ritual." In Companion to Emile Durkheim. Ed. Jeffrey C. Alexander and Philip Smith. Cambridge: Cambridge University Press, 2008. 183-210.

Brewer, Susan A. Why America Fight: Patriotism and War Propaganda from the Philippines to Iraq. Oxford: Oxford University Press, 2011.

Baik, Bong. Kim Il Sung: Biographie (3 volumes). Beyrouth: Dar al-Talia, 1973.

Bourdieu, Pierre. Pascalian Meditations. R. Nice trans. 1997. Cambridge: Polity, 2000.

---. The Logic of Practice. R. Nice trans. Stanford: Stanford University Press, 1990.

Bouthoul, Gaston. La Guerre (4th ed.). 1953. Paris: PUF, 1969.

Butler, Judith. "Violence, Mourning, Politics." In Studies in Gender and Sexuality:1 (2003): 9-37.

---. Precarious Life: The Powers of Mourning and Violence. London, UK: Verso, 2004

---. Frames of War: When Is Life Grievable? New York: Verso, 2009.

Casey, Steven. Selling the Korean War: Propaganda, Politics, and Public Opinion in the United States, 1950-1953. Oxford: Oxford University Press, 2008.

Cho, Grace M. Haunting the Korean Diaspora: Shame, Secrecy, and the Forgotten War. Minneapolis: University of Minnesota Press, 2008.

Choi, Suhi. Embattled Memories: Contested Meanings in Korean War Memorials. Reno: University of Nevada Press, 2014.

Cole, Sarah. "People in War." In The Cambridge Companion to War Writing. Ed. Kate McLaughlin. Cambridge: Cambridge University Press, 2009. 
Conley-Zilkic, Bridget. "What Do You Want? On Witnessing Genocide Today." In The Power of Witnessing: Reflections, Reverberations, and Traces of the Holocaust. Ed. Nancy R. Goodman and Marilyn B. Meyers. London: Routledge, 2012. 319-331.

Deleuze, Gilles and Félix Guattari. Nomadology: The War Machine. New York, NY, USA: Semiotext(e), 1986.

Diehl, James G. Lights! Camera! Action! The Operational Commander and the Media. Fort Leavenworth, KS: School of Advanced Military Studies, US Army Command and General Staff College, 1989.

Dombrowski, Lisa. The Films of Samuel Fuller: If You Die, I'll Kill You! Middletown, Conn: Wesleyan University Press, 2008.

Doss, Erika. Memorial Mania: Public Feeling in America. Chicago: University of Chicago Press, 2010.

Edwards, Paul M. A Guide to Films on the Korean War. Westport, CT: Greenwood Publishing Group, 1997.

Emerson, Rupert. From Empire to Nation. Boston, MA: Beacon Press, 1960.

Foucault, Michel. The Archeology of Knowledge. A. Sheridan trans. New York: Pantheon Books, 1972.

---. The History of Sexuality. vol. 1. R. Hurley trans. 1978. New York: Pantheon Books, 1990.

---. Discipline and Punish: The Birth of the Prison. A. Sheridan trans. New York: Vintage Books, 1991.

Fuller, Samuel. The Big Red One. Preface by Richard Schickle. 1980. New York: Thunder's Mouth Press, 2005.

Grosz, Elizabeth. Space, Time and Perversion: Essays on the Politics of Bodies. London: Routledge, 1995.

Hall, Stuart. "The Determination of News Photograph." In The Manufacture of News: Social Problems, Deviance and the Mass Media. Ed. Stanley Cohen. London: Constable, 1973. 226-242.

Halliday, Jon and Bruce Cumings. Korea: The Unknown War. An Illustrated History. 1988. London: Penguin Books, 1990.

Handel, Michael I. Clausewitz and Modern Strategy. 1996. London: Routledge, 2012.

Harvey, David. Spaces of Hope. Edinburgh: Edinburgh University Press, 2000.

Hartog, François. Regimes of Historicity: Presentism and Experiences of Time. 2003. S. Brown trans. Columbia University Press, 2015.

Hass Kristin A. Sacrificing Soldiers on the National Mall. Berkeley: University of California Press, 2013.

Hastings, Max. The Korean War. 1987. New York: Simon \& Schuster, 2015.

Hayden, Dolores. "Landscape of Loss." In War and Remembrance in the Twentieth Century. Ed. Jay Winter and Emmanuel Sivan. Cambridge, UK: Cambridge University Press, 2000. 142-160.

Hengehold, Laura. The Body Problematic: Political Imagination in Kant and Foucault. University Park, PA: The Pennsylvania State University Press, 2007.

Issermann, Maurice. The Korean War. New York: Infobase Publishing, 2009.

Keleman, Stanley. “Evaluation du corps.” In Sociologie et sociétés 9:2 (1977): 68-78.

Kristeva, Julia. Powers of Horror: An Essay on Abjection. L. S. Roudiez trans. New York: Columbia University Press, 1982. 
Lock, Margaret. "Cultivating the Body: Anthropology and Epistemologies of Bodily Practice and Knowledge." Annual Review of Anthropology 22 (1993): 133-155.

Lynch, René M. “3 sites approved to honor veterans”. In The Record. Washington Post News Service. 29 June 1988.

Marien, Mary Warner. Photography: A Cultural History. 2002. London: Laurence King Publishing, 2006.

McSorley, Kevin. War and the Body: Militarisation, Practice and Experience. New York: Routledge, 2013.

Moïse, Edwin E. "The Myths of the Tet Offensive." In New Perspectives on the History and Historiography of Southeast Asia: Continuing Explorations. Ed. Michael A. Aung-Thwin and Kenneth R. Hall. London, UK: Routledge, 2011. 229-254.

Moores, Shaun. Interpreting Audiences: The Ethnography of Media Consumption. London: SAGE, 1993. National Red Cross of China (ed.). Out of Their Own Mouths, Revelations and Confessions Written by American Soldiers of Torture, Rape, Arson, Looting and Cold-Blooded Murder of Defenceless Civilians and Prisoners of War in Korea. Peking: Red-Cross Society of China, 1952.

Nora, Pierre. "Between History and Memory: Lieux de mémoire.” 1989. M. Roudebush trans. In Historiography: Critical concepts in Historical Studies. vol. IV. Ed. Robert M. Burns. London: Routledge, 2006. 284-302.

Parr, Adrian (ed.). Deleuze Dictionary. Edinburgh: Edinburgh University Press, 2005.

Pick, Daniel. War Machine: The Rationalisation of Slaughter in the Modern Age. 1993. New Haven/ London: Yale University Press, 1996.

Piehler, G. Kurt. Remembering War the American Way. Washington DC: Smithsonian Institution, 1995.

---. "Commemoration and Public Ritual." In The Oxford Companion to American Military History. Ed. J.W. Chambers. New York, NY: Oxford University Press, 1999. 169-171.

Potter, Charles E. Korean War Atrocities: Hearing Before the Subcommittee on Korean War Atrocities of the Permanent Subcommittee on Investigations of the Committee on Government Operations, United States Senate, Eighty-Third Congress, First Session, Pursuant to S. Res. 40. Washington DC: US G.P.O, 1954.

Reckwitz, A. "Toward a Theory of Social Practices. A Development in Culturalist Theorizing." In European Journal of Social Theory 5 (2002): 243-263.

Rottman, Gordon L. Korean War Order of Battle: United States, United Nations, and Communist Ground, Naval, and Air Forces, 1950-1953. Westport, CT: Greenwood Publishing Group, 2002.

Sandler, Stanley. The Korean War: No Victors, No Vanquished. 1999. Lexington: University Press of Kentucky, 2015.

---. The Korean War: An Interpretative History. London: Routledge, 2002.

Scarry, Elaine. The Body in Pain: The Making and Unmaking of the World. Oxford: Oxford University Press, 1985.

Schilling, Chris. "Embodiment, Emotions and the Foundations of Social Order: Durkheim's Enduring Contribution." In Companion to Emile Durkheim. Ed. Jeffrey C. Alexander et al. Cambridge: Cambridge University Press, 2008. 211-238. 
Stanton, Shelby L. US Army Uniforms of the Cold War: 1948-1973. 1994. Mechanicsburg, PA: Stackpole Books, 1998.

Stone, Isidor F. The Hidden History of the Korean War. 1952. New York: Monthly Review Press, 1969. Sumners, Harry G. Jr. Korean War Almanac. New York: Facts on File Inc., 1990.

Thompson, Jenny. War Games: Inside the World of Twentieth-Century War Reenactors. 2004. Washington: Smithsonian Institution, 2014.

UN-DPI (United Nations, Department of Public Information). United Action in Korea under Unified Command; Report to the Security Council. Washington DC: Government Printing Office, 1951.

Villahermosa, Gilberto N. Honor and Fidelity: the $65^{\text {th }}$ Infantry in Korea, 1950-1953. Washington DC: Center of Military History, United States Army, 2009.

Warren, Lynne (ed.). Encyclopedia of Twentieth-Century Photography. London: Routledge, 2005.

Young, Charles S. Name, Rank, and Serial Number: Exploiting Korean War POWs at Home and Abroad. Oxford, England: Oxford University Press, 2014.

---. "Operations Glory and Big Switch." 2014. In The Ashgate Research Companion to the Korean War. Ed. James Irving Matray and Donald W. Boose. Burlington, VT: Ashgate Publishing, Ltd., 2016. 409-420.

\section{Digital images}

“공산주의자들은 한국을 분할 하려고 애쓰고 있다. 유엔은 한국의 동일에 노력 하고 있다", n.d. DigitalPosterCollection, keijo.knutas, 3 Jan. 2016. 20 Feb. 2016.

<http://digitalpostercollection.com/communists-endeavor-to-split-up-korea-the-un-strives-forkoreas-reunification>.

“미제를 몰아내고 조국을 통일하자 !”, 2013. DigitalPosterCollection, keijo.knutas, 3 Jan. 2016. 25 Feb. 2016.

$<$ http://digitalpostercollection.com/lets-drive-the-us-imperialists-our-and-reunite-thefatherland>.

"Be in Style in the Women's Army Corps", 1951. DigitalPosterCollection, keijo.knutas, 22 June 2015. 4 Feb. 2016.

<http://digitalpostercollection.com/1951-be-in-style-in-the-womens-army-corps>.

“Elite Women Marines”, 1952. DigitalPosterCollection, keijo.knutas, 22 Jun. 2015. 5 Feb. 2016. <http://digitalpostercollection.com/1952-elite-women-marines>.

\section{Electronic references}

“MacArthur Statue Prompts Protests in South Korea." Taipei Times, 18 July 2005. 27 Feb. 2016. <http://www.taipeitimes.com/News/world/archives/2005/07/18/2003264019>.

Catalinotto, John. "After 50 Years of Suffering: Tribunal Finds US Guilty of War Crimes in Korea." International Action Center, 27 June 2003. 07 Feb. 2016.

<http://www.iacenter.org/Koreafiles/ktc_guilty.htm>.

Danel, Thibaud-Pascal. "Le cinquante-et-unième état: Une dynamique expansionniste ?" De l'Amérique aux Amériques: dynamiques d'un continent patchwork (November 2014): 14pp. 15 Mars 2016.

<http://halshs-01162961>. 
Joly, Maud. "Corps en guerre. Imaginaires, idéologies, destructions." Quasimodo 8 and 9 (Spring 2005). In Clio. Histoire, femmes et sociétés 30 (2009). 24 March 2010. 2 September 2015.

$<\mathrm{http}: / /$ clio.revues.org/9545>.

Films

Big Fish, dir. Tim Burton, Columbia Pictures, 2003.

Fixed Bayonets, dir. Samuel Fuller, Twentieth Century-Fox, 1951.

Gran Torino, dir. Clint Eastwood, Warner Bros, 2008.

Steel Helmet, dir. Samuel Fuller, Lippert Pictures Inc., 1951.

\section{NOTES}

1. “[C]'est la guerre qui a enfanté l'histoire” (Bouthoul 5). My translation.

2. "La corporalité de la guerre... c'est s'approcher enfin de ceux qui combattent, restés souvent à l'écart de l'effort d'attention." (Audoin-Rouzeau 314) My translation.

3. As it was the case with the total number of combat deaths in Vietnam. Cf. Moïse 239.

4. According to dictionary definitions of the terms, both corporal and corporeal are often used interchangeably. In this paper, however, it will be compelling to operate, in some instances, a distinction between the two. Whereas it seems more natural to use "corporal" (relative to the body) to talk about "corporal punishment" (violence done to physical bodies), for example, the adjective "corporeal" refers to something having (or being given) a corporeal existence.

5. UNTOCK stands for "United Nations Temporary Commission on Korea" though, as Sandler noted, the adjective "temporary" was later dropped (Sandler 2015, 27).

Hastings 2015 similarly mentions the "growing body of Korean officials controll[ing] the bureaucracy of the South Korean Interim Government." (38)

6. Hastings 2015 refers in this case to the absence of any "reliable body of records" in the Chinese archives (132).

7. Cf. "Best Dressed Men on Main Street !" (1950). In Life (18 September 1950, 158).

8. “미제를 몰아내고 조국을 통일하자 !" ("Let's drive the US imperialists out and unify the fatherland!", 2013).

9. A famous picture shows a Korean child forcibly tattooed with the South Korean flag (Young 2014).

10. S. Brewer has similarly emphasized the idea that "the goal was not to mobilize the population, but to elicit its passive support for a faraway conflict." (Brewer 8)

11. Female soldiers were often depicted as nurses and, if not, even elite women marines were likely to be stylish, as they were shown wearing red lipstick, black mascara or eyeliner as in "Be in style in the Women's Army Corps" (1951) and "Elite Women Marines" (1952).

12. North Korean propaganda, during the Korean War and still today during official (and televised) processions, depicts Korea as a single body taking the appearance of a bigger-than-life and powerful soldier crushing American soldiers. This is due to the fact that, for North Korea, the Korean War is not over as long as the US occupies South Korea.

13. The poster in question juxtaposed two pictures. The one on the left showed a Communist soldier ripping the peninsula apart along the $38^{\text {th }}$ Parallel while, on the 
right, a UN soldier was depicted mending it. Cf. "공산주의자들은 한국을 분할 하려고 애쓰고 있다. 유엔은 한국의 동일에 노력 하고 있다." (“Communists try to split up Korea. The UN is working towards Korea's reunification.")

14. "NSC 68: United States Objectives and Programs for National Security"

(April 14, 1950). In Naval War College Review. vol. XXVII (May-June 1975): 51-108.

15. As the two movies featured the same actor (Gene Evans), it could be said that the latter embodies two different visions of the war. Indeed, Fixed Bayonets depicts a mass of soldiers who need one another to survive, emphasizing the group over the individual (unlike The Steel Helmet).

16. The fact that the enemies are referred to as "the Reds", for example, fits in with Cold War teleology and does not acknowledge the Korean War as a civil war.

17. "The wholly defensible, wholly abhorrent, task of warring against civilians was forced upon the Allied airmen by the Communist practice of hiding behind skirts in their stealthy approach to our all-but-beaten defenders of nonmilitant Korean-skirts, literally, skirts figuratively" (Karig 112).

18. The events at Nogeun-ri (also Romanized as No Gun Ri) have been referred to as an "Incident" or a "Massacre." Since the Associated Press broke the story in 1999, historians have discussed the issue a lot (McFarland 327). In any case, Nogeun-ri has become synonymous with the killing of an estimated four hundred civil refugees, shot dead when US troops opened fire from the air and ground (Cho 57). Oral witnesses had talked about the events at Nogeun-ri for a long time before the massacre was acknowledged. Some authors even suggest that Nogeun-ri was "the tip of the iceberg" and that "less notorious incidents involving the killing of civilians" happened (Cho 53). 19. According to Barthes, the distance separating the event and its testimonies decreases as new technologies emerge, causing informative acts of language to substitute with reality or, in this case, with the corporal reality of war. As it can imitate reality "almost perfectly," informative speech raises new methodological questions about war historiography (Barthes 1968, 13).

20. Drawing inspiration from P. Bourdieu and A. Giddens, A. Reckwitz underlined that "social practices are bodily and mental routines" (Reckwitz 256). Boltanski later focused on the "implicit grammatical rules" behind bodily social practices, which are "constituted by the evaluative judgments of ordinary actors" (Basaure 400).

21. Defined as "embodied history" (Bourdieu 1990, 56).

22. Historians will also appreciate the details found in the inner drawstrings and snap fasteners of the ponchos as much as the use of authentic photographs of that era.

23. There already existed a few minor discrepancies in the numbers mentioned by some fund-raising newspapers like Dear Abby which published a letter by Kathleen Cronan (a KWVA member) on 11 November 1988. It mentioned 54,263 deaths and 8,177 MIA while the majority of the press actually used the figures announced by the Pentagon four years after the war $(54,260)$. These figures, however, had been made a little more precise $(54,246)$ by the time the memorial project was voted. These discrepancies could imply that dead bodies were taken as part of a discursive strategy overvaluing or undervaluing casualty figures in order to make the Korean War more significant in the press.

24. J. Butler uses the word "traces" to refer to photographs when they provide "evidence that a break from the norm governing the subject of rights has taken place and that something called "humanity" is at issue here. [...] The visual trace is surely not the same as the full restitution of the humanity of the victim. [...] The photograph, 
shown and circulated, becomes the public condition under which we feel outrage and construct political views to incorporate and articulate that outrage." It should be possible to apply this definition to other cultural artifacts, like films or paintings. Though they operate on different representational levels, the question of authenticity is no longer relevant if the possibility that the bodies they represent were staged is taken in consideration (Butler 2009, 87).

25. Edwards meant by the 'return of the veterans' that, unlike Vietnam War veterans, those who fought in Korea never obtained redemption (Edwards 36-37).

26. The growing attention of official Korean War historians to Puerto Rico (Villahermosa 2009) is quite recent and serves to put US history into question, notably in debates over its integration as the $51^{\text {st }}$ state (Danel 2015).

27. The Sunshine Division is the modern nickname for the $40^{\text {th }}$ Infantry Regiment, which is the National Guard division for California, Nevada, and Utah with member units from across the Western and Pacific US and Oceania. At the time though, it was known as the Grizzly Division (Rottman 31-32).

28. The Encyclopedia of $21^{\text {st }}$ Century photography reads that " $[t]$ he limited visibility of the war meant suppressed recognition of its signal complications. . the comfortable remoteness of the war was set off against a decidely more psychological portrayal of combat in the pictures that did appear in the work of Max Desfor, Carl Mydans, Bert Handy (whose pictures of South Korean War crimes were explicitly censored)" (Warren 1641).

29. According to the International Action Center, American responsibility for war crimes in Korea would have been exposed in front of an international tribunal in June 2003 at the Interchurch Center of New York. The website quoted one of its most active members, John Catalinotto, present at the meeting: "Listening intently to the evidence were over two dozen jurists from 17 countries. [...] After four sessions of deliberating over the testimony, this jury unanimously found the US government and military guilty of 19 counts of war crimes committed against Korea from 1945 until 2001." While North Korean jurists were excluded, the meeting was the culmination of "over a year's work by the Korea Truth Commission" (Catalinotto).

30. Choi 2014 (10) noted that Clinton used the verb regret instead of apologize.

31. The strategy of publishing atrocities pictures on behalf of American historians runs counter to that used during the war, when senior Public Information officers decided that some could "serve a useful purpose in drawing international attention to the crimes of the enemy" (Casey 280).

32. As Clausewitz once argued, what "justifies" war is the extent of the sacrifices done for it. This argument, which compares to Bellah's on civil religion, brings forward the supremacy of politics (Bouthoul 21-22).

33. Though Truman's Executive Order 9981 (1948) provided for the desegregation of the Armed Forces, it was still being enforced during the early months of the Korean War (Sumners 63).

34. The inclusion of African-American bodies in the design of the federal memorial must be taken in the context of the memorial craze as the project was approved alongside two other memorials dedicated to the forgotten chapters of US history (Lynch, " 3 sites approved to honor veterans").

35. For Durkheim, the body is the location of the symbols through which individuals recognize themselves as belonging to a society (Schilling 216). 
36. The episteme is a "total set of relations that unite, at a given period, the discursive practices that give rise to epistemological figures, sciences, and possibly formalized systems; the way in which, in each of these discursive formations, the transitions to epistemologization, scientificity, and formalization are situated and operate [...] the lateral relations that may exist between epistemological figures or sciences in so far as they belong to neighbouring, but distinct, discursive practices"

(Foucault 1972, 211-212).

37. Though statues of national heroes can be found in each of these countries, North Korea has the particularity that it has kept the body of its first president Kim Ilsung, known as the "Eternal President of the Republic" ("공화국의 영원한 주석") under glass since 1994.

38. Before the democratic reconversion of South Korea in 1987, however, it would have been more difficult for the US to talk about a "victory" in East Asia. Such a retrospective historicist approach conveys the idea it was directly responsible for the democratization of the ROK which, in many respects, it was not.

39. The power of legitimate violence is constitutive of what $\mathrm{N}$. Elias called the sociogenesis of the State and may in this respect be linked to the State apparatus and the war machine we described earlier.

40. As in 2005 when a South Korean memorial was vandalized ("MacArthur Statue Prompts Protests in South Korea"). A recent study showed that such debates occurred over the statue of MacArthur in Seoul because he wanted to use the nuclear bomb (Choi 95-114).

41. A regime of historicity was defined by F. Hartog as "the way in which a given society approaches its past and reflects upon it." (Hartog 9)

\section{ABSTRACTS}

This study takes the case of the Korean War (1950-1953) to raise the question of the body as a means of representation in the staging of war and memory in the United States. Given that the "body-war diptych" (M. Joly) is pivotal to understand the corporality of war, this paper endeavors to study how bodies were used in propaganda, pictures, movies, narratives, ceremonies or historical reconstructions to shape the memory of war. Our first concern, thus, in dealing with the use of bodies in a process of remembrance and forgetfulness will be to address the corporality, or corporeality of war in theory before attention is paid to the Korean War itself and to the different historical, political and civic implications of its commemoration in the United States today. Then, considering that the body infers meaning to society in that it produces a symbolic order and impacts on its collective representations, it will be argued that the staging of the bodies of war and memory causes them to articulate a form of nonverbal discourse with a multiplicity of meanings as well as a more pragmatic, sometimes even political, function that must be acknowledged as it makes the history of the Korean War even more delicate to assess given that a "national" idea of the war came to replace its memory.

Cette étude prend le cas de la guerre de Corée (1950-1953) pour soulever la question du corps comme moyen de représentation dans la mise en scène de la guerre et de la mémoire aux Etats- 
Unis. Etant donné que le «diptyque corps/guerre » (M. Joly) est essentiel pour comprendre la corporalité de la guerre, cet article propose d'étudier comment le corps a été utilisé dans la propagande, les images, les films, les récits de guerre, les cérémonies ou les reconstructions historiques pour façonner la mémoire de la guerre. Aussi faut-il, avant d'étudier les usages du corps dans une dynamique de la mémoire et de l'oubli, aborder en premier lieu la corporalité, ou la réalité corporelle de la guerre, en théorie avant de nous intéresser spécifiquement à la guerre de Corée et aux différentes implications historiques, politiques et civiques de sa commémoration aujourd'hui aux Etats-Unis. Sachant que le corps donne du sens à la société du fait qu'il produit un ordre symbolique et affecte ses représentations collectives, on avancera l'idée que la mise en scène des corps de la guerre et de la mémoire induit une forme de discours non verbal dont les significations multiples ainsi que la fonction pragmatique, et parfois même politique, doivent être estimées en ce qu'elles rendent l'histoire de la guerre de Corée plus délicate encore à évaluer puisqu'elles substituent à la mémoire une idée nationale de la guerre.

\section{INDEX}

Mots-clés: guerre de Corée (1950-1953), études américaines, historiographie, représentation, mémoire

Keywords: Korean War (1950-1953), American studies, historiography, representation, memory

\section{AUTHORS}

THIBAUD DANEL

Doctoral student

Université de Nice-Sophia Antipolis

th.pascal.danel@live.fr 